\title{
Family and Systems Therapy and Training in Portugal
}

\author{
Ana Paula Relvas • Madalena Alarcão • M. Graça Pereira
}

\begin{abstract}
The history of systemic family therapy in Portugal since its appearance until the present is discussed. Some data on systemic family therapists' training is provided in the context of the Portuguese Society of Family Therapy and Academic Institutions. In Portugal, family therapy has been extended to various contexts, including medical and community services. Finally, future directions for family and systems therapy practice and training in Portugal are provided emphasizing the importance of family interventions as an important resource to empower families living with health chronic conditions. The Portuguese Family Therapy Society, every 2 years, organizes a scientific Iberian conference with Portuguese and Spanish speakers. This allows the exchange of clinical experience and research about family and systems theory.
\end{abstract}

Keywords Family and systems therapy · Family therapists' training · Family intervention contexts

\section{Introduction}

Due to an opening up to new ideas in the 1970's, especially in political and psychosocial terms, it has only been a little over 30 years since family and systems therapy was introduced in Portugal. It may be recalled that there was a revolution in Portugal in 1974, which overthrew the Salazarist dictatorship and allowed not only the installation of a democratic regime, but also the subsequent incorporation of Portugal into the European Union. In the years that followed, the (almost frenetic) desire for change and the (almost

\author{
A. P. Relvas · M. Alarcão \\ Faculty of Psychology and Education Sciences, University of Coimbra, Coimbra, Portugal \\ e-mail: aprelvas@fpce.uc.pt \\ M. Alarcão \\ e-mail: madalena.alarcao@uc.pt \\ M. G. Pereira $(\bowtie)$ \\ School of Psychology, University of Minho, Campus of Gualtar, 4710-057 Braga, Portugal \\ e-mail: gracep@psi.uminho.pt
}


compulsive) need to connect with the rest of the world led to a whole series of changes which, inevitably and fortunately, were felt in the sphere of mental health and psychotherapy. So, it was in this context that Family Therapy came to Portugal, essentially in two ways: first, via a group of mental health clinicians (particularly psychiatrists, psychologists and social workers); and second, with a more epistemological and theoretical tendency, via a number of academics (particularly linked to psychology departments which were just then being created in Portugal).

Thanks to the profound scientific and clinical changes that have taken place in Portugal and the rest of the world, the interaction between mental health workers and other professionals has become a new challenge for family therapy. Family doctors, nurses, lawyers and professors are just some of the groups of professionals for whom training and methodological intervention proposals, aiming at a systemic approach to reality, have led to a fruitful union with 'psys'. In the context of medical services, family therapy is no longer just aimed at treating families with mentally ill patients, but also at supporting other situations of chronic disease. At the beginning of the twenty-first century, the new legal model of child and youth protection calls for a more active participation of the community in a new partnership with the state, through the local Commissions for Child Protection. As will be later explained, family interventions are, in this context, oriented to support multichallenged families with maltreated or neglected children.

\section{The Beginning of Family Therapy in Portugal}

In 1977, Pina Prata (1924-2011), founder and the reference name of the Portuguese Association of Family and Community Therapy [Associação Portuguesa de Terapia Familiar e Comunitária, APTeFC], organized an intensive training course in family therapy in Lisbon's psychology department (where he was a teacher). This course lasted 3 weeks, 1 week per month, and was directed by Pierre Fontaine and Maggy Siméon from the Chapelle aux Champs Centre. A group of psychiatrists, psychologists, and psychoanalysts, among whom were some of the most respected in the country, took part in this seminar. At around the same time, a few clinicians gathered with the goal of seeking contacts abroad, among the great masters of family therapy. These were to be the founders of the Portuguese Family Therapy Society [Sociedade Portuguesa de Terapia Familiar, SPTF], and they were four psychiatrists (Daniel Sampaio, Helena Silva Araújo, José Gameiro, José Maria Neves Cardoso), two psychologists (Emília Ressano Garcia, José Manuel Almeida Costa), and two social workers (Maria Isabel Fazenda, Maria de Jesus Assis Pacheco), some of whom had training in group analysis. Spurred on by participation in family therapy conferences in Europe, they undertook training in the United States, notably in Palo Alto and with Carl Whitaker, as well as in Italy, with Maurizio Andolfi, among others. It was in the wake of these contacts that the SPTF was formally established in 1979. The same thing happened in the following year, with the APTeFC. These two organizations are still the most representative in the field of family therapy in Portugal.

In 1982, Pina Prata organized the I European Meeting of Family and Community Therapy in Lisbon. This was attended by the biggest names in the field in Europe, and led to the publication of the third and last volume of Cadernos de Psicologia Social Clinica, a scientific journal wholly dedicated to family therapy, in 1983 (the two previous volumes had been published in 1979 and 1981).

In the same year the SPTF started its training courses following a model very close to the format in use today, which, after an average of 5 years training, accredited students as 
family and systems therapists. Between 1985 and 1991, the APTeFC, in collaboration with the Faculty of Medicine in Seville (Spain), promoted a Master's Course in Family Therapy that accredited ten family therapists, all of whom were psychologists. This course was coordinated by Pina Prata and Francisco Ortega Bevia.

In the meantime, two of the SPTF's founding psychiatrists, Daniel Sampaio and José Gameiro, wrote the first book by Portuguese authors on "family therapy" (and this was its title) (Sampaio and Gameiro 1985). Then, the SPTF, at first based solely in Lisbon, embarked on a process of decentralization and so opened regional offices in Coimbra (Centre) and in Oporto (North) in 1995. The organization is currently a NFTO's member (National Family Therapy Organizations) and a EFTA/TIC's member (Training Institutes Chamber).

\section{Family Therapy Training in Portugal Today}

The SPTF has a membership of one thousand five hundred. Furthermore, there are around four hundred accredited family and systems therapists who have various professional backgrounds, with psychologists, social workers, doctors/psychiatrists and nurses predominating, in that order.

Numbers are generally rather boring, but as they do have the advantage of "showing" certain "realities," it is important to go on supplying information that indicates the present 'state' of family therapy in Portugal. The reference will be the association that provides training in a systematic manner, that is, the SPTF. At the moment it has 50 trainers, of whom 20 are supervisors (the last stage of certification in this context). Training is organized into three courses, with progressive technical and theoretical specialization: Introductory Course, Systemic and Family Therapy Course, and Supervision Course. Each of these courses gives the student a diploma but nobody is recognized as a family therapist before their acceptance as an effective member of the SPTF. To be an effective member one has to succeed in the Supervision Course and deliver a public presentation of a clinical report or research study. The teaching hours of each course are shown in Table 1.

The purpose of the Introductory Course is to facilitate the development of an epistemological attitude in keeping with the systemic approach. For this, it is aimed (1) to promote the capacity of trainees to create alternative visions of "realities" and dismantle clichés about the family, other social systems, and their interrelations; (2) to familiarize trainees with some basic concepts of the systemic perspective; and (3) for trainees to acquire the skill of "being able to think systemically."

Regarding the Systemic and Family Therapy Course, the training goals are: (1) to foster theoretical skills in the domain of family and systems therapy models; (2) to carry out

Table 1 Family therapists training program in the portuguese family therapy society (SPTF)

\begin{tabular}{ll}
\hline Introductory course $(60 \mathrm{~h})$ & $60 \mathrm{~h}=56 \mathrm{~h}$ Theory/practice $+4 \mathrm{~h}$ Assessment \\
Systemic and family therapy course & Total/year $-150 \mathrm{~h}$ \\
Years 1 and $2(300 \mathrm{~h})$ & $30 \mathrm{~h}$ Theory $(\mathrm{T})$ \\
& $56 \mathrm{~h}$ Personal training and systemic practice $(\mathrm{P} 1)$ \\
& $40 \mathrm{~h}$ Clinical training $(\mathrm{P} 2)$ \\
& $4 \mathrm{~h}$ Assessment \\
& 20 Credit units $(\mathrm{CU})$ \\
Supervision $(240 \mathrm{~h})$ & $240 \mathrm{~h}(2$ sessions/month; 2 years minimum $)$ \\
Total & $600 \mathrm{~h}$ \\
\hline
\end{tabular}


personal training as preparation for clinical training, and (3) to maximize systemic work inside or outside the professional framework of the trainees.

The 2 years of the course are split into three modules:

- Module 1-focuses on Schools and Models of Family Therapy: (a) appearance of family therapy (1950s and 1960s); (b) classical models (1970s), including Minuchin, Bowen, Palo Alto school, Palazzoli, and others; (c) new developments (1980s and 1990s), such as narrative and collaborative models that include White, De Shazer, Anderson and others; and (d) broadening of family therapy: network, other contexts and multifamily therapy.

- Module 2-centers on personal training and practice of systemic work. The family interview (the setting, the process, and techniques), circular questioning, the systemic hypothesis and reframing, reflexive techniques (like the reflecting team or the As If...exercise), the genogram or family genealogy, and some active techniques are essential topics in this part of the training. The analysis of personal resonances and the interaction between the life-cycle of the therapist and the life-cycle of the family runs transversally throughout this module.

- Module 3-clinical training on the basis of observation, discussion, and analysis of clinical cases in vivo or on video.

Finally, we come to the Supervision Course, which can only be taken after the candidates have passed the other two courses and have undergone a rigorous selection process, based on their professional and clinical backgrounds and relational competences. The aim of this course is to foster the construction of an identity as a family and systems therapist, the acquisition of technical and therapeutic skills, and an ability to reflect and question their own practice. This training is meant for graduate professionals from social and human sciences in general, and from mental health areas in particular-it is a postgraduate training course. Around 250 professionals a year are trained in the various SPTF courses (Headquarters and Regional Offices).

The training model proposed by the SPTF has been summarized. However, it is important to stress that, at the level of pre and postgraduate's higher and academic education, the systemic model and family therapy have been gaining ground and occupying an important place of reference in psychology, social service, or nursing schools, for instance.

Since the 1980s, Coimbra is a major center for training and dissemination of family and marital therapy. In psychology and education departments (University of Coimbra), as well as in the Miguel Torga Institute (a college of social workers), Ana Paula Relvas and Madalena Alarcão have been responsible for the training of several generations of psychologists and social workers, some of whom became successful family therapists or family researchers. At the end of the 1990s they wrote two books that have marked generations of students and family therapists (Alarcão 2000; Relvas 1996). Some years later, Madalena Carvalho and Isabel Alberto joined the team of teachers and family therapists that, at this faculty, teach and investigate in the areas of family psychology and family and marital therapy. In 2002, an issue of Psychologica, one of the scientific periodicals of psychology and education departments, was wholly dedicated to family therapy.

In Lisbon, psychology department has also been doing an important work, teaching family and couple therapy to future psychologists. Isabel Narciso and Maria Teresa Ribeiro are currently responsible for this area. Since 2008, the University of Coimbra and the University of Lisbon have a joint $\mathrm{PhD}$ program — family psychology and family intervention-that aims to develop a set of theoretical, clinical and, research knowledge, as well as competences that 
contribute to a systematic understanding and critical analysis of family functioning within different contexts and modes of family intervention.

In Lisbon, there are two other higher education institutions that provide academic training in systemic theory and family intervention. At ISPA, the first higher education institution in psychological and behavioral sciences in Portugal, people can get a postgraduate degree ( 2 years) in Family Therapy and, with this diploma, they are able to receive accreditation of the second level of the PFTS training program (Systemic and Family Therapy Course). Since 2001, The Autonomous University of Lisbon (UAL), in association with the APTeFC, has provided a postgraduate academic degree (2 years) in Family and Community Therapy, coordinated by Celia Sales (UAL) and Francisco Ortega Bevia (Faculty of Medicine in Seville, Spain).

In the North of Portugal, the University of Minho provides some academic training on family therapy and family psychology at the masters level, and medical family therapy at the doctorate level in the health psychology program. There are other institutions (Faculty of Psychology and Education Sciences of the University of Oporto; University of Trásos-Montes e Alto-Douro; High Institute of Maia) where it is possible to receive some academic training in systemic theories and family intervention, namely a masters degree. The University of Aveiro (center of Portugal) and the University of Évora (south of Portugal) have some courses in systemic therapy. The University of Madeira (Portugal) also has a two-year postgraduate course in Family Therapy and Systems Intervention.

At any rate, it should be noted that training programs, today, are aimed both at the certification of family therapists and at providing a wide variety of professionals with references in order to cultivate and comprehend clinical situations from a systemic perspective. It is intended that systemic ideas may constitute an important tool for those specialists to enrich their own professional specificity.

\section{Family and Systems Therapy in Portugal}

\section{Family and Marital Systemic Therapy in a Traditional Setting}

Current training and practice in family and systemic therapy in Portugal obviously expresses the theoretical and epistemological development of systemic thinking, namely, the positive influence of second-order cybernetics, post-modern constructivism, and social constructionism theories.

Until 1990s, Portuguese family therapists preferred to use a more integrative model rather than following classical schools in a strict way (Relvas 1999). However, they are strongly influenced by Bowen's family systems theory (Bowen 1974, 1978) and his multigenerational lens, Minuchin's structural family theory and therapy (Minuchin 1974; Minuchin and Fishman 1981), the Milan model (Selvini Palazzoli et al. 1978), and the MRI's brief strategic family therapy principles (Haley 1973, 1976; Watzlawick et al. 1974). The systemic hypothesis (Selvini Palazzoli et al. 1980b) was the conductor both for symptom and family functioning conceptualization and for the choice of therapeutic strategies. Reframing and positive connotation were also used as therapeutic approaches for promoting new visions about the family's problem.

Nowadays, family therapists continue to be trained in the old school and family therapy models but make more use of narrative and collaborative models (e.g., Andersen 1991; Anderson and Goolishian 1988, 1990; De Shazer 1994, 2005; White 2007; White and 
Epston 1990; see also McNamee and Gergen 1993). They have also revisited the way they use systemic hypothesis (Cecchin 1987) and reflexive questioning (Tomm 1987, 1988).

Traditionally, Portuguese family therapists are also couple therapists. Also, public and private clinics, where therapists are systemically oriented, offer both family and couple therapy. Sometimes, when the focus of the problem is on the marital system (e.g., communication problems and complaints about lack of attention and affection or misuse of power in the relationship), and when it is important to break rigid triangulation of the children, family therapists finish the family process and propose a new marital-centered therapeutic contract. However, since the 1990s, the voluntary request of couple therapy has been increasing. In Portugal, couple systemic therapists are very influenced by the work of Gameiro (2002) and Caillé (1991).

In several Portuguese universities (e.g., Coimbra, Lisbon, Oporto, Minho), there are services open to the community where it is possible to get marriage or family therapy. In these institutions, as well as at the Portuguese Family Therapy Society, marriage and family therapy occur in a classic setting, with a one-way mirror, co-therapy and observers, as well as video recording sessions. In private practice, by contrast, there is usually a single therapist. Family therapy is also available in some health care centers and hospitals. In the latter, however, family therapy is targeted more towards specific symptoms (e.g., suicide, eating disorders, drug or alcohol abuse). All of these services are concentrated on the coast of Portugal, especially in Coimbra, Lisbon, Porto, Braga, Aveiro.

\section{Systems Therapy Within Medical Services}

Although systems therapy is not always available within medical services, there are some interesting experiences that deserve to be highlighted.

In Coimbra and Aveiro, a program (proFamilies) was developed to support chronically ill patients (cancer and CVA patients) and their families (Sousa et al. 2007), inspired by the work of Rolland $(1984,1987,1990)$. This intervention aims to facilitate family adaptation to chronic illness through the integration of medical social and psychological components, in order to maximize the quality of the family life.

In the Hospital of Braga, in the North of Portugal, integrated in the students'praticum in clinical and health psychology masters programs, several group interventions to support caregivers of chronically ill patients have been developed as well as group interventions for several chronic diseases (e.g. Type 2 diabetes, sleep apnea, breast cancer). In fact, psychoeducational programs, designed to foster couple and family adaptation to illness, when a loved one is affected by chronic disease, are quite common in medical services, hospitals, and health care centers. In these facilities, psychologists, trained in family interventions, integrate multidisciplinary teams.

\section{Systems Therapy in Community Services}

If a first enlargement of family therapy occurred in schools (Selvini Palazzoli et al. 1980a; Evequoz 1987) and other larger system contexts, the decentralization of the family goes even further into the neighborhood (Sluzki 1996) and larger systems levels with which families interact (Imber-Black 1988). Therefore, we can say that, in family therapy, progress has been made from "depathologization" to "defamiliarization" (Relvas 1999). Along with this, ethnic and other minorities or topics like family competences and resilience (Walsh 1998) have definitely entered into the main interests of family therapists and influenced them. The 1980s epistemological reconceptualization, whose objective was a 
renewed respect for systemic complexity, has strengthened the ecological basis of family functioning.

Nowadays, there is a growing number of very vulnerable families, multi-stressed by external stressors (e.g., unemployment, poor environmental living conditions, unsafe neighborhoods) and internal difficulties (poor communications resources, poor parenting models, neglect, violence, difficulty balancing individual and family's needs) that are flagged by negligence and abuse of their children. Known as multi-problem families (Cancrini et al. 1997), they are usually supported by numerous services that are unknown to each other and can have contradictory perspectives and behaviors.

Traditional models and settings of family therapy seem to be insufficient to deal with the complex needs of these families. "In fact, multi-challenged families call for a broadening of the role of the therapist. He or she should work cooperatively with other professionals (...), must work to establish and explore multiple connections with the community in order to help the family (...), establish effective relations with stronger and strategically positioned systems (e.g., neighborhood, extended family, social welfare, community organizations) (...). Research has shown that community-based services may be more suited for [these] multi-challenged families (...), particularly home-based services" (Melo and Alarcão 2011, p. 401) and multi-systemic approaches.

Social services and the child protection system are on the front line of contact with these families, but their professionals cannot always have a truly therapeutic action because they also need to assume a role of social control. Having a basic understanding of systemic thinking is essential for better understanding the challenges that these families and professionals have to deal with. The systemic hypothesis is crucial for a better definition of the intervention that can actively promote family welfare and child safety.

In Portugal, we have developed a model that assesses at-risk families and helps them to change. The IFAIM (Integrated Family Assessment and Intervention Model) is a multisystemic, collaborative, strength-based, and family-focused in-home approach designed to support change in multi-challenged families (Melo and Alarcão 2011). With these families, the therapist must balance between focusing on the family's internal functioning and relations (e.g., chaotic behavior, problems with parenting, emotional and communication difficulties, child maltreatment) and material/instrumental needs or requests (e.g., finding a job, making ends meet, accessing adequate child care, preventing homelessness). This balanced focus will help the family develop a greater sense of control over its life and skills, so that it can master the many challenges that it may face.

With at-risk families, family therapists need to work with the family's informal networks (extended family, neighbors, friends), as proposed by Speck and Attneave (1990) and others (see Elkaim et al. 1995), formal family networks (e.g., health and social services, schools), or both, as proposed by Imber-Black (1988) as well as by Seikkula et al. (2003). Community family therapy is also a great resource for family therapists working in community services because of its focus on (1) personal and family change and growth, (2) accessing community resources, and (3) leadership and civic action (Rojano 2004).

\section{Future Directions for Family and Systems Therapy Practice and Training in Portugal}

Since its beginning, the systemic perspective has involved a break with psychopathology's individualist and analytical view. Later, it was developed and diversified from models created by different schools and extended to other systems. In recent decades, the movement towards a constructivist and constructionist approach, shifted the emphasis to the 
person of the therapist (or observer), and the co-construction of the therapeutic conversation. Strength-based and resilience oriented perspectives have been advocated as a particularly adequate approach for supporting families experiencing multiple risks and different forms of adversity. Cumulative disadvantageous conditions narrow family's sense of authorship, autonomy, and positive identity, thereby disturbing the family's internal relationships and functioning. Professionals must support families pursuing their preferred visions and directions in life while providing appropriate care for their children's and family's welfare.

An aging population and medical advances mean that families are increasingly confronted with chronic disease. In fact, the aging population has brought the need for family intervention in this area. Based on Developmental Health Model (DHM) (Ford-Gilboe 1998), and consistent with the World Health Organization view of health promotion (1978), much of the work, in the health context, adopts a strengths perspective that focuses on how families develop the skills to deal with daily events and work towards health goals. The DHM is a great tool that helps guide family intervention in health care delivery. According to this model, four characteristics contribute to a family's overall pattern of health: health work, health potential, competence in health behavior, and health status. Health work reflects the process of how the family learns problem solving and copes with health conditions. Families learn how to use proactive, problem solving approaches to manage health situations. Health potential reflects the resources and strengths of the family that can be developed through seeking information and support. Competence in health behaviors implies that families are effective in managing health goals, adopting healthier lifestyles, sustaining lifestyle changes, and increasing competent health behavior that reflect in the family's quality and satisfaction with life.

Family Health has progressively become a goal in primary health care, and family interventions, in particular, are designed to empower families handling chronic disease, particularly when patients have been discharged from the hospital and family caregivers are the only resources available to take care of them.

Solution focused approaches, in the management of long term chronic illnesses, fits well with models of empowerment (Christie and Barnard 2012), and multidisciplinary teams, in partnership with families, need to work together to improve self management and quality of life.

Research will also need to include family processes that are influenced by age, class, and culture in order to address differences between groups regarding illness representations, adaptation to disease, and caregiving processes in the pursuit of family health. The articulation of family caregiving, in particular, within the health care delivery system, needs to be addressed. Family therapists will have an important voice in this regard.

Another aspect, that is quite important, is the relationship between marital distress and physical illness. Family interventions and, in particular, family therapy, will need to be part of the treatment offered in medical services, particularly when the patient reports high levels of conflict, in the family and couple relationships. In fact, an unhappy marriage has been called a disability that is analogous to a minority status, economic deprivation, or physical illness (Renne 1970).

Research in marital distress, and its association with physical and psychological illness, will also require the need for more family interventions in health care delivery. In fact, the field of family systems medicine and medical family therapy, in particular, emerged out of the integration of family therapy, systems theory, and modern medicine, emphasizing the family as the primary context for understanding health and illness (McDaniel et al. 1992). Family centered interventions in physical illness, needs to be based on theory and validated 
by applied empirical research. The research group on family, health, and illness (FHI) at the University of Minho, in the North of Portugal, and coordinated by M. Graça Pereira has, for the past years, published a book on family health (Pereira 2007), several papers on relevant family factors in several chronic diseases and developed family centered intervention programs for chronically ill patients and their families. These programs provide family education, enhance family support and help the patient and the family to reframe illness narratives (Pereira 2011). In the future, it will be important for these intervention programs to be empirically assessed, in order to clearly define their impact and promote systemic interventions within the medical services (Mendenhall et al. 2012).

Palliative care and bereavement is another important area where family centered care is particularly important. Research has shown that some family types are at an increased risk for poorer social outcomes. In these families, members report higher levels of psychological morbidity, psychopathology, somatization, and poor overall social functioning and social adjustment (Schuler et al. 2012).

Hospice and Palliative care are a relatively new specialty in medical practice based on the family unit as the unity of care. Palliative care services have increased acceptance of the need for family centered interventions in order to assess family needs. Most of the interventions, in this setting, deal with communication, cohesion, support levels solving differences in conflict, particularly in relational patterns, and coping responses to loss (Kissane et al. 2003). In this setting, family issues tend to be related to the disease process and how the family unit is coping with the family member's deterioration. Across the country, more units of palliative care have been created and family interventions are being included in the care delivered. In fact models, such as the "transitions and palliative care therapy model" (Babcock and Robinson 2011), based on a family systems approach, have been very helpful in guiding family interventions.

Overall, there is a growing recognition that families need to be supported and celebrated. Family-centered care is an emerging philosophical framework out of which health care services can be planned and delivered.

Two other challenges that Portuguese family and couple therapists are increasingly confronted with are: (1) multiculturalism (Portugal has received immigrants from many countries in recent years) and (2) the experience of marriage and parenthood inside homosexual dyads. Family violence, on the other hand, is a reality already well known, although, offspring's violence against parents is starting to be a problem requiring new answers. Also, with the economic crisis, that, in these last few years struck Europe, family therapy, in Portugal, will need to build upon the families' resilience in the face of adversity. This will enable therapists to bring forward experiences of connection and hope while working with these marginalized families due to economic hardship.

Finally, more rigorous research in Family Therapy is needed regarding its effectiveness and efficacy in the field of mental and physical health, in order to be acknowledged as an important treatment option within psychological and medical services (Tyndall et al. 2012) and, particularly, in the arena of integrated primary care (Marlowe et al. 2012).

In terms of training, in November of 2008, the Portuguese Family Therapy Society (Sociedade Portuguesa de Terapia Familiar, SPTF) and the Spanish Federation of Family Therapy Associations (Federación Españhola de Asociaciones de Terapia Familiar, FEATF) signed a cooperation protocol for the exchange of clinical experience and research about family and systems therapy. Every two years, there will be an Iberian scientific conference with both Portuguese and Spanish speakers. Since 2009, Mosaico, the scientific journal of FEATF, opened up to collaboration with Portuguese researchers as well as to all published articles from Spanish and Portuguese therapists and researchers in the area of family and systemic therapy. 
In 2013, an e-learning training project in family therapy began, based on a partnership between the psychology and education departments of the University of Coimbra, the Vasco Navarra School of Family Therapy (Bilbau) and the Family Therapy School of Sant Pau Hospital (Autonomous University of Barcelona). These courses are taught in Spanish and Portuguese. The 1st edition is also open to Brazilian's students but we are also aiming to integrate students from other Portuguese-speaking countries.

We hope that family therapy in Portugal will continue to develop academically and professionally as well as become more integrated into the community's delivery of services, particularly to help families at risk.

\section{References}

Alarcão, M. (2000). (des) Equilíbrios familiares. Uma visão sistémica [Family imbalances. A systemic overview]. Coimbra: Quarteto Editora.

Andersen, T. (1991). The reflecting team: Dialogues and dialogues about dialogues. New York: Norton \& Company.

Anderson, H., \& Goolishian, H. (1988). Human systems as linguistic systems: Evolving ideas about the implications for theory and practice. Family Process, 27(4), 371-393. doi:10.1111/j.1545-5300.1988. 00371.x.

Anderson, H., \& Goolishian, H. (1990). Beyond cybernetics; Comments on Atkinson and heath's further thoughts on second order family therapy. Family Process, 29(2), 157-163. doi:10.1111/j.1545-5300. 1990.00145.x.

Babcock, C. W., \& Robinson, L. E. (2011). A novel approach to Hospital Palliative care: An expanded role for counselors. Journal of Palliative Medicine, 14(4), 491-500. doi:10.1089/jpm.2010.0432.

Bowen, M. (1974). La différentiation du soi, les triangles et les systèmes emotifs familiaux [The differentiation of the self, triangles and family emotional systems]. Paris: ESF.

Bowen, M. (1978). Family therapy in clinical practice. New Yok: Jason Aronson.

Caillé, P. (1991). Un et un font trois. Le couple révelé à lui-même [One and one make three. The couple revealed itself]. Paris: ESF.

Cancrini, L., De Gregorio, F., \& Nocerino, S. (1997). Las famílias multiproblemáticas. Im M. Coletti \& J. L. Linares (Eds.), Las familias multiproblemáticas [The multi-problem families] (pp. 45-82). Barcelona: Paidós.

Cecchin, G. (1987). Hypothesizing, circularity and neutrality revisited: An invitation to curiosity. Process, 26(4), 405-414. doi:10.1111/j.1545-5300.1987.00405.x.

Christie, D., \& Barnard, K. D. (2012). Supporting resilience and positive outcomes in families, children and adolescents. In K. Barnard \& C. E. Lloyd (Eds.), Psychology and diabetes care: A pratical guide (pp. 47-689). London: Springer. doi:10.1007/978-0-85729-573-6_3.

de Shazer, S. (1994). Words were originally magic. New York: Norton \& Company.

de Shazer, S. (2005). More than miracles: The state of the art of solution-focused therapy. Binghamtom: Haworth Press.

Elkaim, M. et al. (1995). Las practicas de la red [Networkig practices]. 2nd edn. Barcelona: Gredisa.

Evequoz, G. (1987). Le contexte scolaire et ses otages [The school environment and its hostages]. Paris: ESF.

Ford-Gilboe, M. (1998). An overview of the developmental health model. London, Ontario: Canada University of Western Ontario, School of Nursing.

Gameiro, J. (2002). Terapia de casal. [Marital therapy]. Psycologica, 31, 43-48.

Haley, J. (1973). Uncommon therapy: The psychiatric techniques of Milton H. Erickson. New York: Norton \& Company.

Haley, J. (1976). Problem solving therapy. San Francisco: Jossey-Bass.

Imber-Black, E. (1988). Families and larger systems. A family therapist's guide through the labyrinth. New York: Guilford Press.

Kissane, D., McKenzie, M., McKenzie, D., Forbes, A., O’Neill, I., \& Bloch, S. (2003). Psychosocial morbidity associated with patterns of family functioning in palliative care: Baseline data from the family focused grief therapy controlled trial. Palliative Medicine, 17, 527-537. doi:10.1191/02692 16303 pm808oa. 
Marlowe, D., Hodgson, J., Lamson, A., White, M., \& Irons, T. (2012). Medical family therapy in a primary care setting: A framework for integration. Contemporary Family Therapy, 34(2), 224-258. doi: 10.1007/s10591-012-9195-5.

McDaniel, S., Hepworth, H., \& Doherty, W. J. (1992). Medical family therapy. New York: Guildforf Press.

McNamee, K. J., \& Gergen, S. K. J. (Eds.). (1993). Therapy as social construction. London: Sage Publications.

Melo, A., \& Alarcão, M. (2011). Integrated family assessment and intervention model: A collaborative approach to support multi-challenged families. Contemporary Family Therapy, 33, 400-416. doi: 10.1007/s10591-011-9168-0.

Mendenhall, T. J., Pratt, K. J., Phelps, K. W., \& Baird, M. A. (2012). Advancing medical mixed-methods design. Contemporary Family Therapy, 34(2), 187-203. doi:10.1007/s10591-012-9186-6.

Minuchin, S. (1974). Families and family therapy. Cambridge, MA: Harvard University Press.

Minuchin, S., \& Fishman, H. C. (1981). Families and family therapy. Cambridge, MA: Harvard University Press.

Pereira, M. G. (2007). (Ed). Psicologia da saúde familiar: Aspectos teóricos e Investigação [Family health psychology: Theoretical aspects and intervention]. Climepsi Editores. Lisboa.

Pereira, M. G. (2011). (Ed). Promoção da saúde psicossocial na doença: Aspectos teóricos e intervenção [Promotion of psychosocial health within illness:Theoretical aspects and intervention]. Viseu: Psicossoma.

Relvas, A. P. (1996). O ciclo vital da família: Perspectiva sistémica [The family lyfe cycle: Systemic perspective]. Porto: Afrontamento.

Relvas, A. P. (1999). Conversas com Famílias. Discursos e perspectivas em terapia familiar [Conversations with families. Discourses and perspectives in family therapy]. Porto: Afrontamento.

Renne, K. (1970). Correlates of disatisfaction in marriage. Journal of Marriage and the Family, 32, 54-67.

Rojano, R. (2004). The practice of community family therapy. Family Process, 43(1), 59-77. doi: 10.1111/j.1545-5300.2004.04301006.x.

Rolland, J. (1984). Toward a psychosocial typology of chronic and life: Threatening illness. Family Systems Medicine, 2(3), 245-262.

Speck R. von \& Attneave, C. (1990). Redes familiares (L. Wolfson, Trad.) [Family networks]. $2^{\circ}$ ed. Buenos Aires: Amorrortu Editores. (Original work published 1973).

Rolland, J. (1987). Chronic illness and the life cycle: A conceptual framework. Family Process, 26(2), 203-221. doi:10.1111/j.1545-5300.1987.00203.x.

Rolland, J. (1990). Anticipatory loss: A family systems developmental framework. Family Process, 29(3), 229-244. doi:10.1111/j.1545-5300.1990.00229.x.

Sampaio, D., \& Gameiro, J. (1985). A terapia familiar [Family Therapy]. Porto: Afrontamento.

Schuler, T. A., Zaider, T. I., \& Kissane, D. W. (2012). Family Grief Therapy. A vital model in oncology, palliative care and bereavement. Australian Institute of Family Studies, 90, 77-86.

Seikkula, J., Arnkil, T. E., \& Eriksson, E. (2003). Postmodern society and social networks: Open and anticipation dialogues in network meetings. Family Process, 42(2), 185-203. doi:10.1111/j.1545-5300. 2003.42201.x.

Selvini Palazzoli, et al. (1980a). Le magicien sans magie [The magician without magic]. Paris: ESF.

Selvini Palazzoli, M., Boscolo, L., Cecchin, G., \& Prata, G. (1978). Paradox and contreparadox. New York: Jason Aronson.

Selvini Palazzoli, M., Boscolo, L., Cecchin, G., \& Prata, G. (1980b). Hypothesizing-circularity-neutrality: Three guidelines for the conductor of the session. Family Process, 19, 3-12. doi:10.1111/j.1545-5300. 1980.00003.x.

Sluzki, C. (1996). La red social: Frontera de la pratica sistémica [Social network: At the Border of systemic practice]. Barcelona: Gedisa.

Sousa, L., Mendes, A., \& Relvas, A. P. (2007). Enfrentar a velhice e a doença crónica [Facing old age and chronic illness]. Lisboa: Climepsi Editores.

Tomm, K. (1987). Interventive interviewing: Part II. Reflexive questioning as a means to enable selfhealing. Family Process, 26(2), 167-183. doi:10.1111/j.1545-5300.1987.00167.x.

Tomm, K. (1988). Interventive interviewing: Part III. Intending to ask lineal, circular, strategic, or reflexive questions? Family Process, 27(1), 1-15. doi:10.1111/j.1545-5300.1988.00001.x.

Tyndall, L. E., Hodgson, J. L., Lamson, A. L., White, M., \& Knight, S. M. (2012). Medical family therapy: A theoretical and empirical review. Contemporary Family Therapy, 34(2), 156-170. doi:10.1007/ s10591-012-9183-9.

Walsh, F. (1998). Strengthening family resilience. NewYork: The Guilford Press.

Watzlawick, P., Weakland, J. H., \& Fish, R. (1974). Change: Principles of problem formation and problem resolution. New York: Norton. 
White, M. (2007). Maps of narrative practice. New York: Norton \& Company.

White, M., \& Epston, D. (1990). Narrative means to therapeutic ends. New York: Norton \& Company. World Health Organization. (1978). Alma Ata Declaration. Denmark: Copenhaguen. 